\title{
Numerical Simulation of an Argon Stirred Ladle with Top and Bottom Injection
}

\author{
Sofia Torres, Miguel A. Barron* \\ Departamento de Materiales, Universidad Autonoma Metropolitana Azcapotzalco, Mexico City, Mexico \\ Email: ^bmma@correo.azc.uam.mx
}

How to cite this paper: Torres, S. and Barron, M.A. (2016) Numerical Simulation of an Argon Stirred Ladle with Top and Bottom Injection. Open Journal of Applied Sciences, 6, 860-867. http://dx.doi.org/10.4236/ojapps.2016.613075

Received: November 1, 2016

Accepted: December 3, 2016

Published: December 6, 2016

Copyright $\odot 2016$ by authors and Scientific Research Publishing Inc. This work is licensed under the Creative Commons Attribution International License (CC BY 4.0).

http://creativecommons.org/licenses/by/4.0/

\begin{abstract}
The stirring of a molten steel ladle with argon injection through a top submerged lance and a bottom nozzle is numerically studied here through Computational Fluid Dynamics (CFD) simulations. Three lance submergence depths and three injection velocities are considered in the CFD numerical experiments. The turbulent dissipation rate is employed to characterize the stirring phenomenon. The mixing times are determined from the gas flow rate, ladle geometry and bath depth using an empirical correlation.
\end{abstract}

\section{Keywords}

Argon Injection, CFD Simulations, Gas Stirring, Mixing Time, Molten Steel Ladle, Stirring Efficiency

\section{Introduction}

Nowadays, ladle metallurgy or secondary metallurgy is an important technology to obtain high quality steel products which satisfy strict norms and specifications of mechanical performance [1]. Among the ladle metallurgy operations, one can find processes like decarburization, desulphurization, degasification, inclusions removal, and so on. In this processes, stirring of the molten steel in the ladle is indispensable to get high chemical reaction rates, thermal homogenization and inclusion elimination. Two main techniques are employed to attain molten metal agitation: electromagnetic stirring and argon gas stirring. Argon gas stirring is preferred given that it does not require expensive equipment. It is fast and it does not contaminate the metal bath due to the inert nature of argon.

Commonly, argon is injected into the metal bath through submerged lances or through porous plugs located at the bottom of the ladle. Both procedures have pros and cons, as is reported in the specialized literature. In [2] it is affirmed that in gas stirred 
systems, the mixing is a combination of convection and eddy diffusion processes. For the authors of that report, the mixing time depends on the specific input energy rate, the vessel radius and the molten metal depth. Besides, an empirical equation is proposed there to estimate the mixing time in axisymmetric systems. In cold model experiments, the mixing of a water bath under gas injection through a rotary submerged lance is studied in [3]. There, the effect of the gas flow rate, the rotation speed and the water depth on the mixing performance is analyzed. It is reported that the gas flow rate plays a significant role for deep baths. In [4], a comparative study of mixing phenomena in gas stirred ladle systems is carried out. Mixing performance of ladles of several geometries is compared using empirical correlation previously developed and reported by the same authors.

Using Computational Fluid Dynamics (CFD) numerical simulations, in [5] it is concluded ladle height is the most important factor which determines the mixing efficiency. Besides, it is reported that gas injection through multiple tuyeres is a promising strategy for improving mixing, however, the success of this strategy depends on the tuyere arrangement. On the other hand, in [6] it is reported that the turbulent dissipation rate is a key parameter that influences the mixing performance of stirred ladles with axial impellers.

In this work, the stirring performance of a molten steel bath in a 150 metric tons ladle with argon injection through a top submerged lance and a bottom nozzle is numerically analyzed using transient 2-D two-phase isothermal CFD numerical simulations. Three lance submergence depths and three injection velocities are considered in the CFD numerical experiments. As in [6], the turbulent dissipation rate is employed to characterize the stirring phenomenon for each of the considered injection velocities. Finally, mixing times are determined from the gas flow rate, ladle geometry and bath depth using the empirical correlation reported in [3]. The main geometrical parameters of the considered 150 metric tons ladle are shown in Figure 1.

\section{Mathematical Model and Numerical Solution}

For the sake of simplicity, full equations of the mathematical model are not written here given that they can be found elsewhere [7]. The flow of molten steel in a ladle under gas stirring is mathematically modeled by the Navier-Stokes equations and the continuity equation. Turbulence in the considered system can be simulated by means of the classical two equations K- $\varepsilon$ model [8] [9]. This model, in spite that yields time averaged results, provides good numerical stability during long time integration calculations. Besides, the two-phase argon-molten steel flow is addressed by means of the Volume of Fluid (VOF) model [10], which considers that all the present phases share the same flow field. The mass conservation principle implies that the whole of the phase volume fractions sums the unity [11].

CFD software [11] was employed to numerically solve the mathematical model. A mesh convergence test was carried out to determine the optimal mesh size. In accordance with the results of this test, a mesh with around 71,000 trilateral cells yields consistent 
results. Transient 2-D two-phase (argon and molten steel) isothermal computer simulations were carried out during $15 \mathrm{~s}$ of integration time using time steps of $0.001 \mathrm{~s}$. The geometrical dimensions of the 150 metric tons ladle were as follows (see Figure 1): D1 = $3.0 \mathrm{~m}, \mathrm{D} 2=3.16 \mathrm{~m}, \mathrm{~h}=3.12 \mathrm{~m}$. A two-nozzle submerged lance was assumed. Three values of the lance submergence depth $(\mathrm{H})$ were considered: 1,2 and $3 \mathrm{~m}$. The diameter of the lance nozzles and the bottom nozzle were $\mathrm{D}_{\mathrm{n}}=0.05 \mathrm{~m}$. The physical properties of molten steel were as follows: density $7100 \mathrm{~kg} / \mathrm{m}^{3}$, viscosity $0.0067 \mathrm{~kg} /(\mathrm{m} \cdot \mathrm{s})$. The physical properties of argon were as follows: density $1.6228 \mathrm{~kg} / \mathrm{m}^{3}$, viscosity $2.125 \times 10^{-5} \mathrm{~kg} /$ $(\mathrm{m} \cdot \mathrm{s})$. The PISO (Pressure Implicit with split Operator) algorithm was employed for the pressure-velocity coupling. Boundary conditions for argon injection velocities of 0.1 , 0.5 and $1.0 \mathrm{~m} \cdot \mathrm{s}^{-1}$ are shown in Table 1 . They were calculated using the expressions reported in [12].

\section{Results and Comments}

Evolution of the phase distribution and streamlines for argon bottom injection are shown in Figure 2 for an injection velocity of $0.5 \mathrm{~m} \cdot \mathrm{s}^{-1}$. Argon bubbles ascend from the bottom to the free surface and, as they ascend, the molten bath becomes stirred and mixed. Initially, as is seen in Figure 2(a), just the bottom of the ladle is stirred, however,

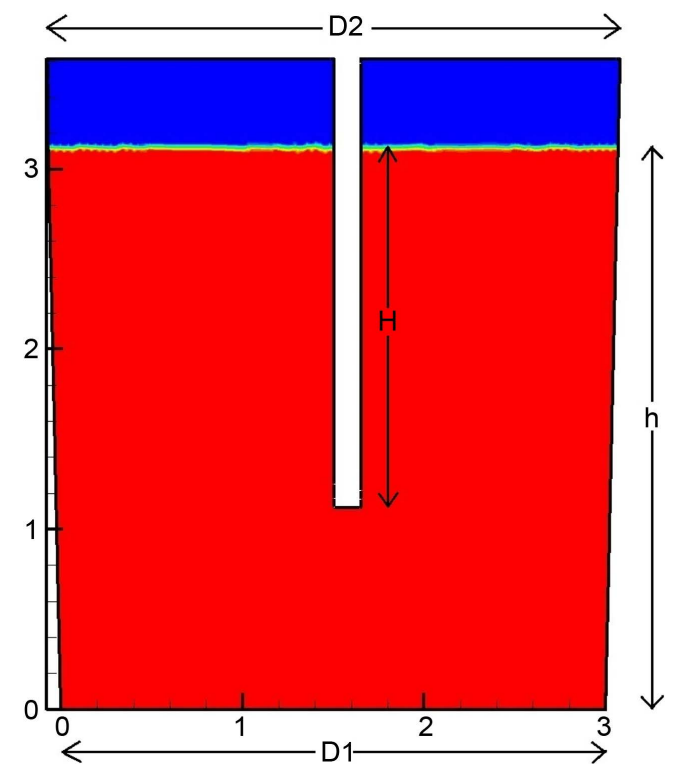

Figure 1. The parameters of the 150 metric tons ladle. The phases shown are: molten steel (red) and argon (blue).

Table 1. Boundary conditions at nozzles.

\begin{tabular}{ccc}
\hline Argon injection velocity $\left(\mathrm{m} \cdot \mathrm{s}^{-1}\right)$ & Turbulent kinetic energy $\left(\mathrm{m}^{2} \cdot \mathrm{s}^{-2}\right)$ & Turbulent dissipation rate $\left(\mathrm{m}^{2} \cdot \mathrm{s}^{-3}\right)$ \\
\hline 0.1 & $1.0 \times 10^{-4}$ & $4.0 \times 10^{-5}$ \\
0.5 & $2.5 \times 10^{-3}$ & $5.0 \times 10^{-3}$ \\
1.0 & $1.0 \times 10^{-2}$ & $4.0 \times 10^{-2}$ \\
\hline
\end{tabular}


as time proceeds, the whole volume of the molten metal becomes shaken. In the case of submerged lance injection, argon bubbles ascend from the lance tip to the free surface, as is observed in Figure 3. Due to bubbles buoyancy, and depending on the lance submergence depth, few bubbles succeeded in reaching the bottom of the ladle. This means that for submerged lance injection the molten metal located at the ladle bottom remains unshaken during the very initial steps of injection, as is appreciated in Figure 3.

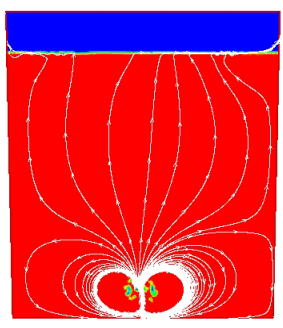

(a)

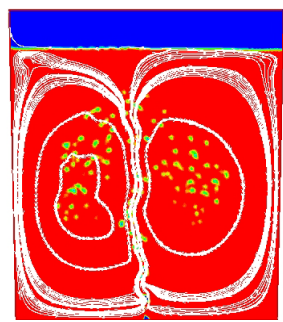

(c)

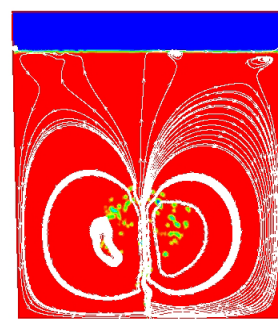

(b)

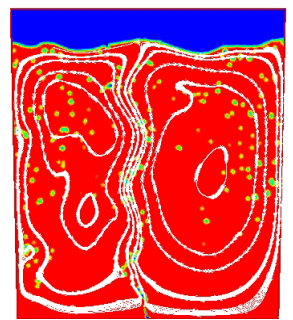

(d)

Figure 2. Evolution of the phase distribution and streamlines for bottom injection of argon. Red is molten steel; blue is argon; yellow is a mix of steel and argon. Injection velocity: $0.5 \mathrm{~m} \cdot \mathrm{s}^{-1}$. Time(s): (a) 1.0, (b) 3.0, (c) 5.0, (d) 11.0.

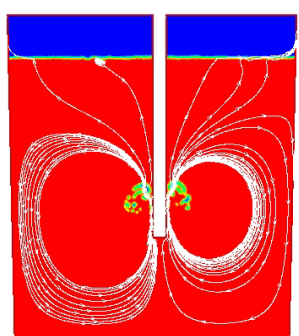

(a)

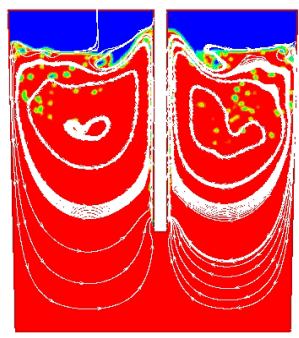

(a)

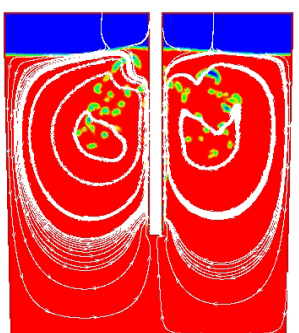

(b)

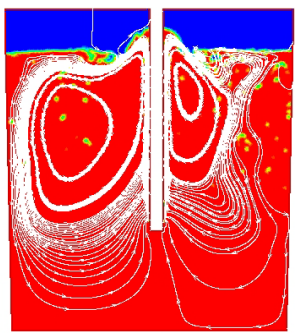

(b)

Figure 3. Evolution of phase distribution and streamlines for submerged lance argon injection. Injection velocity $=0.5 \mathrm{~m} \cdot \mathrm{s}^{-1}$, lance submergence depth $=2.0 \mathrm{~m}$. Time(s): (a) 1.0, (b) 3.0, (c) 5.0, (d) 11.0. 
The effect of the submergence depth of lance on the phase distribution and bath stirring is shown in Figure 4. For a low submergence depth, see Figure 4(a), argon bubbles quickly reach the free surface, however, the major portion of the bath remains unstirred. As the submergence depth is increased, argon bubbles are discharged deeper into the metal bath and ascend to the free surface at longer times. For $3 \mathrm{~m}$ of lance submergence depths, see Figure 4(c), argon bubbles are deeper introduced to the metal bath, in a manner that resembles to the bottom injection case. As the submergence depth increases, the ladle bottom becomes more stirred. Figure 4 shows that a molten metal crater is formed around the lance at the free surface when the argon is injected through a submerged lance. This phenomenon is absent in the bottom injection case, where a surface wave is formed at the top of the ladle.

As in [6], the turbulent dissipation rate is employed here as the main parameter to quantify the stirring efficiency. Figure 5 depicts the evolution of the mass average turbulent dissipation rate for the argon bottom injection case, for the three considered injection velocities. As the argon injection velocity is increased, the dissipation rate is increased too. This means that the mixing efficiency is raised as the injection velocity grows. On the other hand, Figure 6 shows the evolution of the mass average turbulent dissipation rate for the case of submerged lance argon injection as function of the lance

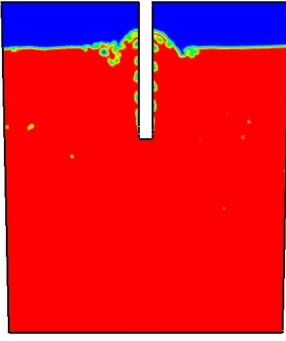

(a)

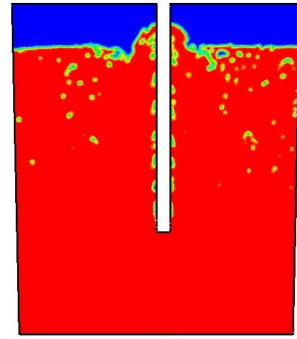

(b)

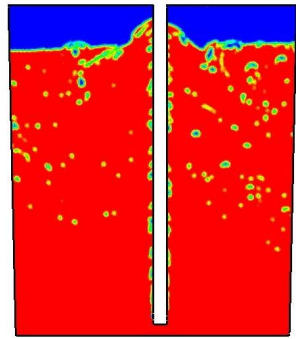

(c)

Figure 4. Evolution of phase distribution for submerged lance argon injection as function of the lance submergence depth. Results shown are for an argon injection velocity of $0.5 \mathrm{~m} \cdot \mathrm{s}^{-1}$ and time of $11 \mathrm{~s}$. Lance submergence depth: (a) $1.0 \mathrm{~m}$, (b) $2.0 \mathrm{~m}$, (c) $3.0 \mathrm{~m}$.

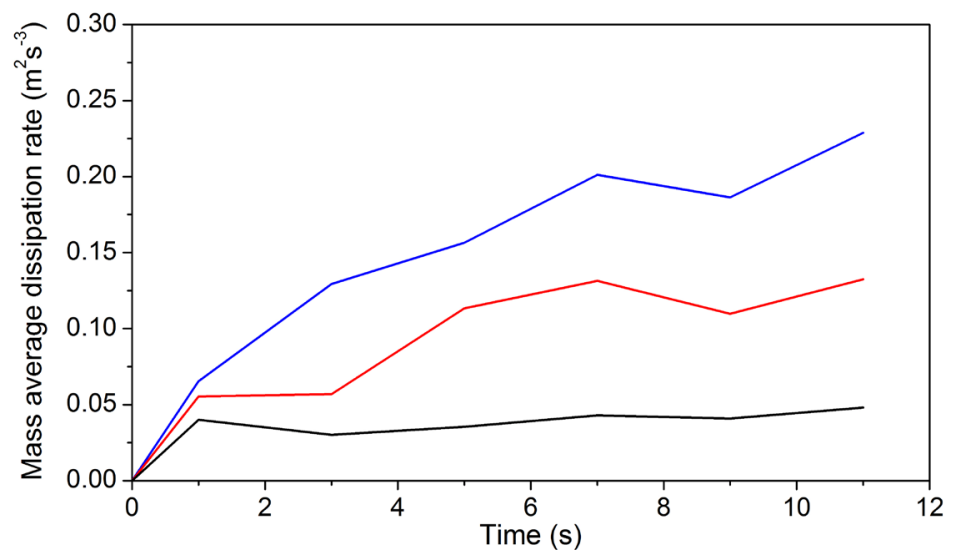

Figure 5. Evolution of the mass average turbulent dissipation rate for argon bottom injection. Injection velocity $\left(\mathrm{m} \cdot \mathrm{s}^{-1}\right): 0.1$ (black), 0.5 (red). 1.0 (blue). 


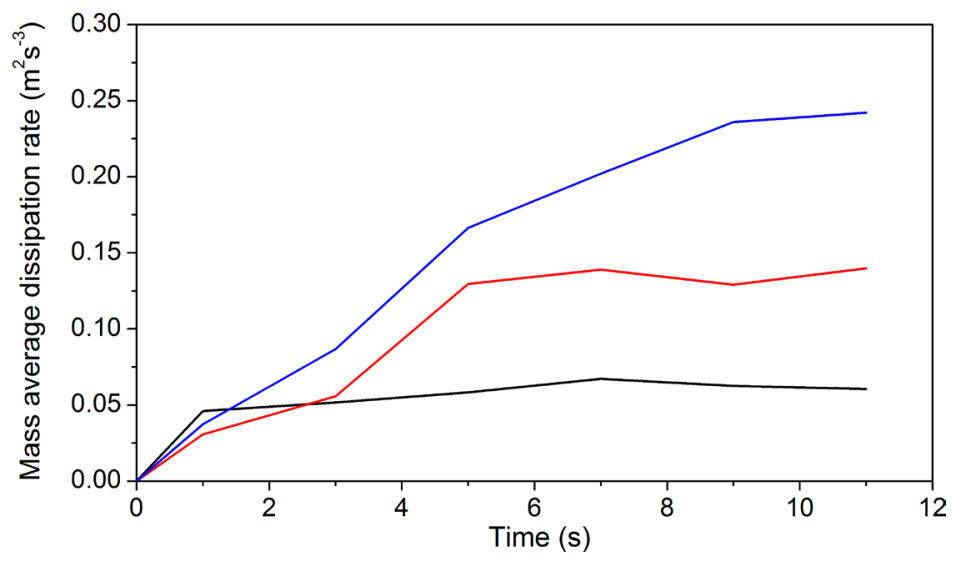

Figure 6. Evolution of the mass average turbulent dissipation rate for submerged lance argon injection. Injection velocity $=0.5 \mathrm{~m} \cdot \mathrm{s}^{-1}$. Lance submergence depth (m): 1.0 (black), 2.0 (red), 3.0 (blue).

submergence depth. In Figure 6 the injection velocity is kept constant at $0.5 \mathrm{~m} \cdot \mathrm{s}^{-1}$, and the considered lance submergence depths are 1.0, 2.0 and $3.0 \mathrm{~m}$. One can observe that the turbulence dissipation rate is increased as the lance submergence depth is increased. However, by comparing Figure 5 and Figure 6 (red lines) it is observed that for an injection velocity of $0.5 \mathrm{~m} \cdot \mathrm{s}^{-1}$ the turbulent dissipation rate for the bottom injection is similar than that corresponding to the submerged lance injection with $2.0 \mathrm{~m}$ of submergence depth. One would expect that, for the same injection velocity, the results for the bottom injection and the submerged lance injection with $3.0 \mathrm{~m}$ of submergence depth would be analogous, however this does not occur. This discrepancy is due to the fact, in the computer simulations, the bottom plug has just one nozzle, whereas the submerged lance has two injection nozzles, therefore the argon flow rates are different when the same injection velocity is considered.

Mixing time $\left(\tau_{m}\right)$ can be defined as the time (commonly in seconds) required for achieving a certain degree (around 95\%) of homogeneity (chemical or thermal) of an injected tracer in a unit operation vessel [13]. Given the difficulty to derive a theoretical expression for determining $\tau_{m}$, frequently empirical correlations are used in the literature and at industry. In this work, the following empirical expression reported in [4] is employed to estimate the value of this important parameter:

$$
\tau_{m}=25.4 Q^{-0.33} R^{2.33} h^{-1}
$$

where $Q$ is the argon injection flow rate $\left(\mathrm{m}^{3} \cdot \mathrm{s}^{-1}\right) ; R$ is the mean radius of the ladle $=(D 1+$ $D 2) / 4$ (see Figure 1); and $h$ is the depth of molten bath in the ladle $(m)$. Originally, Equation (1) was derived for stirred cylindrical vessel with gas injection through a central, vertically submerged lance containing water. However, the authors of [4] affirm that Equation (1) provides good estimation of mixing times that are in reasonable agreement with reported experimental data. In the present calculations, the following values were employed: $D 1=3.0 \mathrm{~m}, D 2=3.16 \mathrm{~m}, R=1.54 \mathrm{~m}, h=3.12 \mathrm{~m}$. $Q$ was determined through the expression $Q=N_{n} v A$, where $N_{n}$ is the number of nozzles at the injection point, $v$ is the argon injection velocity and $A$ is the nozzle flow area. $A$ is determined 
Table 2. Mixing times of a 150 metric ton ladle with $2.0 \mathrm{~m}$ of submergence depth of lance. From Equation (1).

\begin{tabular}{ccc}
\hline Argon injection velocity $\left(\mathrm{m} \cdot \mathrm{s}^{-1}\right)$ & Argon volumetric flow rate for a two nozzles lance $\left(\mathrm{Nm}^{3} \cdot \mathrm{s}^{-1}\right)$ & Mixing time $(\mathrm{s})$ \\
\hline 0.1 & $3.9270 \times 10^{-4}$ & 296.18 \\
0.5 & $1.9635 \times 10^{-3}$ & 174.14 \\
1.0 & $3.9270 \times 10^{-3}$ & 138.54 \\
\hline
\end{tabular}

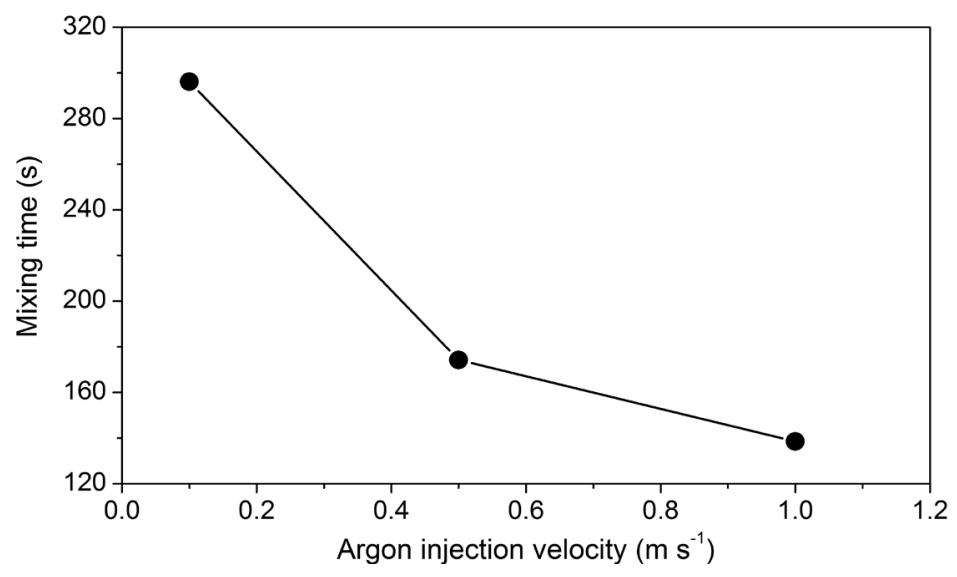

Figure 7. Mixing time as function of argon injection velocity for submerged lance injection.

from the nozzle diameter, $D_{r}$. Then, $A=\pi D_{n}^{2} / 4$, and $v=0.1,0.5$, and $1.0 \mathrm{~m} \cdot \mathrm{s}^{-1}$. In the cases considered here, for the bottom nozzle $N_{n}=1$ and for the submerged lance $N_{n}=$ 2. Table 2 shows the calculated mixing times for the submerged lance injection case estimated from Equation (1) using the above values of variables. The second column of Table 2 shows the argon volumetric flow rate corresponding to the considered injection velocities of column 1 , whereas the third column shows the mixing time in seconds. In Figure 7 one can observe that as the injection velocity (and hence the argon flow rate) is increased, the mixing time is decreased.

\section{Conclusions}

The stirring of a 150 metric tons molten steel ladle with argon gas using bottom and top submerged lance injection was numerically studied using a Computational Fluid Dynamics tool. Three injection velocities and three lance submergence depths were considered in the computer simulations. Based on the analysis of the computer results, the following conclusions arise:

1) For the submerged lance injection, the mixing efficiency is increased as the lance submergence depth is increased.

2) For the ladle geometry considered, the mixing time strongly depends on the argon flow rate for the case of submerged lance injection. In fact, an empirical correlation shows that the mixing time decreases as the argon flow rate is increased.

3) During the initial steps of the process, the bottom injection exhibits more mixing efficiency than the submerged lance injection. 


\section{References}

[1] Cramb, A.W. (2003) The Making, Shaping and Treating of Steel. Continuous Casting Volume. AISE Steel Foundation, Pittsburgh.

[2] Mazumdar, D. and Guthrie, R.I.L. (1986) Mixing Models of Gas Stirred Metallurgical Reactors. Metallurgical Transactions B, 17B, 725-733. https://doi.org/10.1007/BF02657134

[3] Diaz, M.C., Iida, T., Komarov, S.V. and Sano, M. (1995) Mixing Characteristics under Gas Injection through Rotary Lance Submerged in Liquid Bath. ISIJ International, 35, 464-471. https://doi.org/10.2355/isijinternational.35.464

[4] Mazumdar, D., Das, S. and Bajpayee, S. (1997) A Comparative Study of Mixing Phenomena in Gas Stirred Ladle Systems. ISIJ International, 37, 194-196.

https://doi.org/10.2355/isijinternational.37.194

[5] Cloete, S.W.P., Eksteen, J.J. and Bradshaw, S.M. (2013) A Numerical Modelling Investigation into Design Variables Influencing Mixing Efficiency in Full Scale Gas Stirred Ladles. Minerals Engineering, 46-47, 16-24. https://doi.org/10.1016/j.mineng.2013.03.014

[6] Delafosse, A., Collignon, M.L., Crine, M. and Toye, D. (2011) Estimation of the Turbulent Kinetic Energy Dissipation Rate from 2D-PIV Measurements in a Vessel Stirred by an Axial Mixel TTP Impeller. Chemical Engineering Science, 66, 1728-1737. https://doi.org/10.1016/j.ces.2011.01.011

[7] Bird, R.B., Stewart, W.E. and Lightfoot, E.N. (2002) Transport Phenomena. 2nd Edition, Wiley, New York.

[8] Launder, B.E. and Spalding, D.B. (1974) The Numerical Computation of Turbulent Flows. Computer Methods in Applied Mechanical Engineering, 3, 269-289.

https://doi.org/10.1016/0045-7825(74)90029-2

[9] Thomas, B., Yuan, Q., Sivaramakhrisnan, S., Shi, T., Vanka, S.P. and Assar, M.B. (2001) Comparison of Four Methods to Evaluate Fluid Velocities in a Continuous Slab Casting Mold. ISIJ International, 41, 1262-1271. https://doi.org/10.2355/isijinternational.41.1262

[10] Hirt, C.W. and Nichols, B.D. (1981) Volume of Fluid (VOF) Method for the Dynamics of Free Boundaries. Journal of Computational Physics, 39, 201-225. https://doi.org/10.1016/0021-9991(81)90145-5

[11] (2003) Fluent 6.1 User's Guide. Lebanon, NH.

[12] Solorio-Díaz, G., Morales, R.D., Palafox-Ramos, J., García-Demedices, L. and RamosBanderas, A. (2004) Analysis of Fluid Flow Turbulence in Tundishes Fed by a Swirling Ladle Shroud. ISIJ International, 44, 1024-1032. https://doi.org/10.2355/isijinternational.44.1024

[13] Ascanio, G. (2015) Mixing Time in Stirred Vessels: A Review of Experimental Techniques. Chinese Journal of Chemical Engineering, 23, 1065-1076. 
Submit or recommend next manuscript to SCIRP and we will provide best service for you:

Accepting pre-submission inquiries through Email, Facebook, LinkedIn, Twitter, etc. A wide selection of journals (inclusive of 9 subjects, more than 200 journals)

Providing 24-hour high-quality service

User-friendly online submission system

Fair and swift peer-review system

Efficient typesetting and proofreading procedure

Display of the result of downloads and visits, as well as the number of cited articles

Maximum dissemination of your research work

Submit your manuscript at: http://papersubmission.scirp.org/

Or contact ojapps@scirp.org 